\title{
Epizod wojennej biografii Jana Parandowskiego. Majątek Planta pod Opatowem
}

\section{Grażyna PaWlak}

ORCID: 0000-0002-4952-583I

(Instytut Badań Literackich PAN, Warszawa)

Okres wojny, a szczególnie dwa jej ostatnie lata, w życiu Jana Parandowskiego stanowiły zagadkę dla wielu badaczy. Tym większą, że sam zainteresowany wspominał o nim z rzadka i raczej w skąpych słowach. Najczęściej można znaleźć informacje, że podczas okupacji mieszkał w Warszawie ${ }^{\mathrm{I}}$ lub pod Warszawą ${ }^{2}$, niekiedy dodawano enigmatycznie „mieszkał w majątku k. Opatowa”, „,ukrywał się na wsi pod Sandomierzem”4. Nawet w pierwszej serii Stownika wspótczesnych pisarzy polskich, wydawanego przez Instytut Badań Literackich PAN, można przeczytać, że Parandowski dopiero „po powstaniu warszawskim zamieszkał na wsi”s. Pojawiły się także zgoła kuriozalne doniesienia, jak zaprezentowane przez Mirosława A. Supruniuka we wstępie do tomu Grydzewianów, że Parandowski wzorem Jana Lechonia, Kazimierza Wierzyńskiego i Józefa Wittlina po klęsce Francji opuścił Polskę i wyemigrował do USA ${ }^{6}$.

Najwyższy więc czas wypełnić tę lukę i spróbować odpowiedzieć na pytanie, kim byli ludzie, którzy ryzykując tak wiele, zaprosili pisarza z żoną Żydówką

1 Jako przykład można wskazać hasło osobowe Jan Parandowski w wielu współczesnych kompendiach: W. Maciąg, w: idem, Literatura Polski Ludowej 1944-1964, Warszawa 1973, s. 423; R. Matuszewski, w: Literatura polska XX wieku. Przewodnik encyklopedyczny, t. 2: P-Z, Warszawa 2000, s. 8; J. Termer, Leksykon prozaików dla szkót i mitośników literatury, Warszawa 2001, s. 554; M. Tabor, w: Biografie stawnych ludzi, t. 2, Bochnia 2006, s. 306.

2 M. Wańkowicz, Anoda i katoda, t. 1, wstęp A. Szwedowicz, Warszawa 2011, s. 498.

3 Biogramy uczonych polskich, cz. 1: Nauki spoteczne, z. 3: P-Z, oprac. A. Śródka, P. Szczawiński, Wrocław 1985, s. 32. We wszystkich cytatach zachowano pisownię i interpunkcję oryginału.

4 B. Tuszyński, Polscy olimpijczycy XX wieku (1924-2002): N-Ż, Wrocław 2004, s. 434.

5 Stownik wspótczesnych pisarzy polskich, t. 2: J-P, oprac. zespół pod red. E. Korzeniewskiej, Warszawa 1964, s. 611.

6 M. Grydzewski, Silva rerum, wybór J.B. Wójcik, M.A. Supruniuk, Warszawa 2014, s. 88. 
i dwójką dzieci pod swój dach, w jakich warunkach przyszło im mieszkać i jakich zajęć się podejmowali. Nie mniej ciekawa wydaje się nader oszczędna relacja żony Parandowskiego, zamykająca dwuletni pobyt w majątku Morawskich na niespełna dwóch stronicach wspomnieniowej książki Dzień Jana. Warto także zwrócić uwagę na pełen dystansu stosunek Parandowskiego do ludzi, którzy w najtrudniejszym momencie otworzyli przed nim podwoje własnego domu, prawdopodobnie ratując mu życie. Poza dostępnymi opracowaniami ogromną pomocą $\mathrm{w}$ tym zakresie służyły autorce niepublikowane dotychczas materiały oraz relacje trójki żyjących jeszcze dzieci ostatniego właściciela Planty, Stanisława Morawskiego.

Do opuszczenia Warszawy skłoniły Parandowskich przybierający na sile terror, szczególnie wobec ludności niearyjskiej, oraz dwukrotna nocna wizyta gestapo w mieszkaniu. Choć żona pisarza zainteresowanie gestapo łączyła z osobą mieszkającego u nich sublokatora ${ }^{7}$, to przypuszczalnie oboje mieli świadomość, że jej pochodzenie stanowi realnie śmiertelne niebezpieczeństwo. $Z$ godziny na godzinę dotychczasowy adres stawał się coraz bardziej niepewny. W połowie 1942 roku Niemcy rozpoczęli zakrojoną na szeroką skalę akcję brutalnej eksterminacji Żydów8 . Prześladowania ujawniły całą grozę polityki niemieckiej wobec ludności żydowskiej. Do obozów śmierci w Bełżcu, Sobiborze czy położonej w pobliżu Warszawy Treblinki wywieziono tysiące ofiar. Pozostali, zamknięci w gettach, mogli jedynie czekać na to, co przyniesie los. Ci, którzy zostali w stolicy, powoli znikali. Krąg przyjaciół i znajomych stale się kurczył, niektórzy ginęli, inni umierali z wyczerpania. Z rąk niemieckiego okupanta ponieśli śmierć Rafał Blüth i Tadeusz Boy-Żeleński, ludzie z kręgu bliskich Parandowskiemu „Wiadomości Literackich”; zmarł Wacław Berent, dzięki któremu pisarz mógł rozpocząć nowy etap w Warszawie; odszedł rozstrzelany w Palmirach Witold Hulewicz, a jego brat Jerzy, przytłoczony tą wiadomością, umarł przy sztalugach; w tej samej zbiorowej egzekucji zabito Stefana Napierskiego. W przypadku Parandowskiego wyjazd z Warszawy okazał się decyzją o fundamentalnym znaczeniu. Niearyjskie pochodzenie żony, które w środowisku nie było tajemnicą, w każdej chwili mogło stać się wyrokiem śmierci dla całej rodziny. Były prezes PEN Clubu Ferdynand Goetel pisał wprost: „Prezes P.E.N. Clubu Jan Parandowski nie dawał znaków życia. Było

7 I. Parandowska, Dzień Jana, Warszawa 1983, s. 71, 73.

8 Było to wdrożenie zaleceń konferencji, która odbyła się w willi przy ulicy Grosser Wansse 56/58 w Berlinie, 20 stycznia 1942 r., pod przewodnictwem szefa policji bezpieczeństwa i SD, Reinharda Heydricha. Naradę zwołano w celu poinformowania wysokich rangą urzędników III Rzeszy o planowanym, globalnym rozwiązaniu kwestii żydowskiej, jak określano zamiar ludobójstwa Żydów w Europie. Wykonanie tego zadania Heinrich Himmler zlecił Głównemu Urzędowi Bezpieczeństwa Rzeszy. Uczestnicy konferencji mieli jedynie omówić najbardziej efektywny sposób eksterminacji społeczności żydowskiej. 
to zrozumiałe, skoro miał żonę pochodzenia żydowskiego" ${ }^{9}$. We wrześniu 1942 roku rodzina opuściła warszawskie mieszkanie przy ulicy Filtrowej 69, by kolejne dwa lata wojny spędzić w majątku Planta pod Opatowem, należącym do rodziny Morawskich. Wedle wspomnień najstarszego syna podróżowali koleją, a ostatnie kilometry ze stacji Ostrowiec Świętokrzyski do Planty pokonali bryczką, przysłaną przez właścicieli majątku. Prawdziwym wyzwaniem w całej podróży okazał się przejazd przez posterunki niemieckie w okolicach Radomia, ale, jak pokazują dalsze losy, i tę przeszkodę udało się szczęśliwie pokonać. W jednym z opowiadań Parandowski nawiązywał wprost do tych wydarzeń:

\section{\Ofiarowano nam gościnę we dworze w okolicy Opatowa, w miejscu „spokojnym”, odległym od ważniejszych dróg, kolej nie przechodziła tamtędy, ale do stacji, oddalonej o trzydzieści kilometrów, jechało się przez Radom ${ }^{\text {IO }}$.}

Również na stronach diariuszowych zapisków zachowały się notatki potwierdzające wyjazd z Warszawy we wrześniu I942 roku ${ }^{\text {II }}$.W tych okolicznościach zaproszenie rodziny pisarza pod swój dach było ze strony Stanisława i Olgi Morawskich - rodziców trzynaściorga dzieci: ośmiu córek i pięciu synów - aktem niebywałej odwagi i prawdziwej solidarności w nieszczęściu. Zarówno dla właścicieli majątku, jak i wszystkich jego mieszkańców, a tych w owym czasie przygarnęła rodzina całkiem sporo, udzielenie schronienia choćby jednemu przedstawicielowi nacji żydowskiej równało się wyrokowi śmierci dla pozostałych. Zgoda na pobyt Parandowskiego z rodziną we dworze musiała mieć głębsze uzasadnienie. Niewykluczone, że jej korzenie sięgają czasów internowania obu stron w Rosji w czasie pierwszej wojny światowej. W tym właśnie okresie późniejszy właściciel Planty, Stanisław Morawski, w charakterze poddanego pruskiego został wraz z rodzicami (Tadeuszem Morawskim oraz Marią z Iżyckich Morawską) i rodzeństwem przesiedlony do Kijowa, gdzie podjął pracę jako administrator dóbr Michałowskich na Podolu. W I9I7 roku, uchodząc przed rewolucją bolszewicką, osiadł w Saratowie. Tam zaangażował się w prace komitetu pomocy dla polskich uchodźców, między innymi przy organizacji szpitala dla ludności polskiej i sierocińca dla sierot wojennych. Za tę działalność został uhonorowany adresem dziękczynnym od Komitetu Polskiego do spraw uchodźców ${ }^{\mathrm{I} 2}$. Podobnie zaledwie dwudziestoletni wówczas Parandowski, podlegający zarządzeniom gu-

9 F. Goetel, Czasy wojny, Londyn 1955, s. 26.

10 J. Parandowski, Wrześniowa noc, Warszawa 1962, s. 25.

11 Idem, Luźne kartki, Wrocław 1967, s. 241.

12 S. Leitgeber, Morawscy herbu Natęc I. 600 lat dziejów rodziny, Poznań 1997, s. 280-281. 
bernatora Galicji, jako jeniec cywilny przebył drogę ze Lwowa przez Woroneż do Saratowa. Tam dał się poznać jako aktywny działacz Domu Polskiego, w którym, wspólnie z pierwszą żoną, Aurelią Wyleżyńską, prowadził odczyty i spotkania zarówno dla przesiedleńców, jak i osiadłej w tym mieście Polonii. Nicią splatającą losy Parandowskiego i Stanisława Morawskiego były więc Saratów i zaangażowanie obu stron w prace prężnie działającej w tym mieście kolonii polskiej. Być może wówczas zostały nawiązane pierwsze kontakty, które ćwierć wieku później okazały się dla pisarza bezcenne - wtedy to dla Morawskiego Parandowski mógł jawić się jako towarzysz niedoli z całkiem nieodległej przeszłości, z którym łączyło go doświadczenie internowania w carskiej i bolszewickiej Rosji. Z relacji córki Stanisława Morawskiego, Teresy Leitgeber, wynika natomiast, że podczas wojny Parandowscy znaleźli schronienie w Plancie dzięki bezpośredniej interwencji żony Kajetana Morawskiego. Maria z Turnów Morawskiej zwróciła się w tej sprawie o pomoc do mieszkającego z dala od stolicy kuzyna ${ }^{\mathrm{I3}}$. W czasie wojny w jej warszawskim mieszkaniu organizowano konspiracyjne zebrania, w których brał także udział autor Dysku olimpijskiego. Stąd zapewne wiedziała o niebezpieczeństwie zagrażającym pisarzowi i jego rodzinie. Stanisław Morawski zdecydował się zaprosić pod swój dach Parandowskiego z dwójką dzieci i żoną Żydówką, mimo śmiertelnego niebezpieczeństwa grożącego za ukrywanie Polaków pochodzenia żydowskiego. $Z$ opowieści córki wynikało, że były co najmniej dwa powody tak ryzykownej decyzji ojca.Jeden to wielka sympatia dla Marii z Turnów Morawskiej, której prośbom dziedzic Planty nigdy nie odmawiał, drugi to utrwalony przez pokolenia chrześcijański kodeks postępowania względem bliźniego, szczególnie - bliźniego potrzebującego pomocy. Jak wyjaśniała córka, ugruntowana wiara i ludzka przyzwoitość nakazywały tak właśnie postąpić. Rodzina Morawskich należała do grupy ziemian, która w okresie okupacji sprawowała funkcje opiekuńcze wobec ofiar wojny: dawali uciekinierom nie tylko dach nad głową i utrzymanie, ale także tworzyli warunki do pracy twórczej, co potwierdzają zarówno relacje potomków rodziny Morawskich, jak i Ireny Parandowskiej.

Do mieszkańców dworu z pewnością docierały wieści z oddalonego zaledwie o trzynaście kilometrów Opatowa o okrucieństwie Niemców wobec ludności niearyjskiej. Na miesiąc przed przybyciem Parandowskich, w sierpniu 1942 roku, rozpoczęła się akcja wywozu młodych Żydów z Opatowa, a pod koniec października hitlerowcy przystąpili do likwidacji getta, utworzonego w mieście zaledwie przed kilkoma miesiącami ${ }^{\mathrm{I}}$. Z całą bezwzględnością ścigali ukrywających się w oko-

13 Relacja córki, Teresy z Morawskich Leitgeber, rozmowa z autorką przeprowadzona 20 października $2016 \mathrm{r}$.

14 A. Sułowski, U podnóża Gór Świętokrzyskich. Z dziejów obwodu Opatów ZWZ-AK 1939-1945, Warszawa 1987 , s. 32 . 
licznych wsiach $\dot{Z} y d o ́ w$, rozstrzeliwując całe rodziny za to, że wbrew niemieckim zarządzeniom ośmieliły się ukrywać rodzinę żydowską lub tylko ich dziecko. Groza czyhającego niebezpieczeństwa była odczuwalna na każdym kroku. Dla Parandowskiego musiała być tym większa, że miał świadomość proweniencji żony oraz śmiertelnego zagrożenia, na jakie naraża pozostałych współmieszkańców. Jak wspominała jedna z córek Morawskich: „semickie rysy żony Parandowskiego były łatwe do rozpoznania, a wyjaśnienia o ormiańskim rodowodzie pani Ireny raczej nikogo specjalnie nie przekonywały"15. Być może to zaważyło na późniejszej negatywnej percepcji Planty?

Wedle wspomnień Franciszka Morawskiego i Anny Hajduk, dzieci ostatniego właściciela Planty ${ }^{16}$, podczas okupacji cała rodzina czynnie działała w ruchu oporu. We dworze udzielano wszelkiej możliwej pomocy oddziałom partyzanckim. Stanisław Morawski był członkiem Związku Walki Zbrojnej (ZWZ), następnie Armii Krajowej oraz przedstawicielem Rady Głównej Opiekuńczej (RGO) w powiecie opatowskim. Synowie współdziałali z grupami partyzanckimi, a córki były łączniczkami i sanitariuszkami w zgrupowaniu AK w Iwaniskach.

W Plancie znalazło schronienie wielu ludzi, którzy podobnie jak Parandowscy musieli opuścić swoje domy, uciekając przed gestapo lub na skutek przymusowego wysiedlenia. Na początku wojny do majątku przyjechała liczna grupa kuzynów i krewnych Morawskich, a w końcu września 939 roku dołączyła jeszcze grupa osób wysiedlonych z Poznania. Rodzina Parandowskich, z dwójką nastoletnich dzieci, dotarła do posiadłości we wrześniu 1942 roku. Zamieszkali w jednym z pokoi $\mathrm{z}$ alkową, od wystroju wnętrza nazywanego „zielonym”, usytuowanym w najstarszej, reprezentacyjnej części dworu. Według wspomnień żony Parandowski został oficjalnie zarejestrowany w majątku jako „Mölkerei bericht”, czyli przygotowujący sprawozdania mleczarskie ${ }^{\mathrm{I} 7}$, co w razie najścia żandarmów uzasadniało pobyt i wyjaśniało posiadanie akcesoriów pisarskich. Sporą część mieszkańców dworu stanowili przedstawiciele przedwojennej elity intelektualnej. Poza Parandowskimi w pamięci rodzeństwa (Franciszka Morawskiego, Teresy Leitgeber i Anny Hajduk) ${ }^{\mathrm{I}}$ pozostał profesor Stefan Błachowski, którego pisarz poznał podczas studiów we Lwowie.

15 Relacja córki, Teresy z Morawskich Leitgeber, rozmowa z autorką przeprowadzona 20 października $2016 \mathrm{r}$.

16 Planta. Franciszek Morawski opowiedziat historie rodzinnego majatku w Plancie, [not.] A. Gromek-Gadkowska, „Ziemia Opatowska” 2000, nr 17, s. 8-13; A. Hajduk, W kolejce po równośc. Polska 1945-1956 w opowieściach kobiet. Rozmowę przeprowadziła Anna Kaczorowska. Sygn. nagrania: AHM_2857. Miejsce nagrania: Wolsztyn; data nagrania: 15 listopada 2012 r. Format: mp3, Warszawa: Ośrodek Karta. Archiwum Historii Mówionej.

17 I. Parandowska, Dzień Jana, s. 74.

18 Relacja córki, Anny z Morawskich Hajduk, rozmowa z autorką przeprowadzona 21 października $2016 \mathrm{r}$. 
Dawny asystent profesora Kazimierza Twardowskiego po odzyskaniu przez Polskę niepodległości przeniósł się do Poznania, by zasilić tamtejszą kadrę uniwersytecką. Bezpieczną przystań w Plancie znaleźli również poznański chirurg Kazimierz Nowakowski z żoną i najmłodszym synem oraz dziennikarz i poeta Jan Smotrycki z żoną. W tym okresie w posiadłości Stanisława Morawskiego mieszkał także jego brat, Edward Morawski. Ten przedwojenny senator Rzeczypospolitej, wysiedlony przez Niemców z majątku Karmin koło Pleszewa, podczas okupacji zarządzał wybudowanym przez rodzinę tartakiem w Iwaniskach ${ }^{\text {19 }}$. Do obiadu - jak wspominał Franciszek Morawski - zasiadało codziennie około 40 osób, a zdarzyło się raz w czasie wojny, że przy stole zajęło miejsce aż 168 osób ${ }^{20}$. Nic zatem dziwnego, że posiłki były zazwyczaj skromne, a jadłospis dość monotonny. Mięso podawano zaledwie kilka razy do roku, uzupełniając jego braki nabiałem i jarzynami. Na śniadanie serwowano zupę mleczną z kaszą lub makaronem. Dodatkowo na stole stały tace $\mathrm{z}$ chlebem smarowanym marmoladą lub powidłami domowego wyrobu. Masło należało do luksusów, a dzieci najczęściej musiały zadowolić się suchym chlebem. Obiady zazwyczaj były jednodaniowe, prym wiodły zupy jarzynowe, zakwaszane niekiedy ogórkami i kiszoną kapustą. Latem jadłospis wzbogacano o zupy owocowe, jagodowe i grzybowe, w dużej części przygotowywane z owoców lasu, które chętnie zbierali mieszkający we dworze poznaniacy. Drugie danie komponowano najczęściej z jarzyn (buraczki, marchewka, ziemniaki) oraz jajek. Na kolację niemal zawsze podawano ziemniaki i zsiadłe mleko, o które we dworze było stosunkowo łatwo. W warunkach wojennych nie mogło być inaczej, każdy majątek ziemski miał wyznaczony kontyngent nierogacizny i płodów rolnych, egzekwowany przez Niemców z całą surowością. Właściciel majątku mógł tylko raz w roku zabić na własny użytek jedną z kolczykowanych świń. Wówczas w plantowskiej kuchni pojawiały się takie potrawy jak gulasz czy bigos, ziemniaki okraszano słoniną, a do chleba podawano salceson czy pasztetówkę. Mięsem gospodarowano oszczędnie, żeby go na dłużej starczyło. Do zaopatrzenia spiżarni wykorzystywano również to pochodzące z zabitych przez bomby lub pociski zwierząt domowych, w tym nawet koni. Edward Morawski wspominał sytuację, gdy w Plancie od uderzenia bomby zginął źrebak - jego szczątki podawano jako młodą wołowinę w obawie, że nikt nie zechce jeść koniny.

19 Edward Morawski (1892-1961), ziemianin i dyplomata. W latach 1920-1930 w czynnej służbie MSZ, m.in. oddelegowany do Międzysojuszniczej Komisji Rządzącej i Plebiscytowej na Górnym Śląsku; 1926-1927 sekretarz RP w Bukareszcie; 1938-1939 senator V kadencji Senatu RP. Po wojnie, pozbawiony majątku dekretem o reformie rolnej, zamieszkał w Poznaniu. W 1952 r. oskarżony o szpiegostwo na rzecz Francji został skazany na 8 lat więzienia. W 1957 r. uniewinniony decyzją Sądu Najwyższego. Zob. J.M. Zawadzki, Senatorowie. Losy wojenne i powojenne, Warszawa 2012, s. 297.

20 Relacja syna, Edwarda Morawskiego, rozmowa z autorką przeprowadzona 22 października 2016 r. 
Po zamknięciu przez Niemców w pobliskich Iwaniskach szkół powszechnych ${ }^{21}$, które zamieniono na magazyny zbożowe, właściciel Planty, Stanisław Morawski, zdobył pozwolenie na uruchomienie szkółki dla czterdzieściorga czworga dzieci folwarcznych ${ }^{22}$. Placówka formalnie pozostawała pod zarządem niemieckim i mogła realizować jedynie ograniczony program szkoły powszechnej. Władze okupacyjne zezwoliły na naukę czytania, pisania i liczenia po niemiecku. Według nakazu rolę podręcznika miało odgrywać czasopismo „Stern” i na jego podstawie odbywała się w Plancie nauka jawna. Poza legalną szkółką lekcje w Plancie prowadzono również w ramach tajnego nauczania. Córki właściciela dworu, Maria i Anna, organizowały na terenie majątku tajne komplety szkolne dla młodzieży zamieszkałej we dworze i w Iwaniskach, wywodzącej się głównie z rodzin przesiedleńców. Dzięki zabiegom przejawiającej talenty pedagogiczne Anny Morawskiej na tajnych kompletach starano się realizować przedwojenny program szkoły średniej ogólnokształcącej. Do nauki wykorzystywano podręczniki gospodarza, pochodzące jeszcze sprzed wielkiej wojny oraz te, które udało się zdobyć wśród znajomych i krewnych. Obok przedmiotów programowych obligatoryjnie wprowadzono język niemiecki, uznając, że jego znajomość pomoże chronić młodych ludzi w razie niespodziewanego najścia żandarmów. Egzaminy końcowe składano u dyplomowanych nauczyli szkół w Iwaniskach i Opatowie ${ }^{23}$. Uczestnicy kompletów otrzymywali dodatkowo zaświadczenia o zatrudnieniu na folwarku, wydawane przez Stanisława Morawskiego. Dla bezpieczeństwa młodzież często pojawiała się w ogrodzie, polu lub zabudowaniach gospodarczych, wykonując rozmaite prace, które miały uwiarygodnić ich częstą obecność na terenie majątku. Anna Morawska, absolwentka Liceum Handlowego w Iwaniskach ${ }^{24}$, uczyła historii, geografii, języka francuskiego, a bywało, że z powodu braku nauczycieli lista przedmiotów okazywała się znacznie dłuższa. Do grona jej uczniów należały również kilkunastoletnie dzieci Parandowskich - Romana i Zbigniew.

Wśród wysiedleńców i uciekinierów nie brakowało przedwojennych pedagogów, którzy wspomagali w prowadzeniu zajęć młodziutką, bo zaledwie dziewiętnastoletnią organizatorkę. Młodzież chętnie z nich korzystała, ponieważ jedyna zarejestrowana w powiecie opatowskim szkoła handlowa była odpłatna. „Istnienie tajnych kompletów stanowiło wśród ludności tajemnicę publiczną. Mimo to na

21 Tak w relacji córki, Anny z Morawskich Hajduk, rozmowa z autorką przeprowadzona 21 października $2016 \mathrm{r}$.

22 A. Hajduk, w: N. Gabis, Żotnierze niezwyciężonej szkoty. Wspomnienie o nauczycielach tajnego nauczania w latach 1939-1945, Zielona Góra 1993, s. 69.

23 Ibidem, s. 69-72.

24 Tak w relacji córki, Anny z Morawskich Hajduk, rozmowa z autorką przeprowadzona 21 października 2016 r. 
terenie powiatu opatowskiego nie było wypadku doniesienia okupantowi o tajnej nauce" - podkreślał Tadeusz Bernat ${ }^{25}$. Na rozwój szkolnictwa średniego ogólnokształcącego w obrębie powiatu opatowskiego miały wpływ ówczesne warunki i wymuszona migracja ludności. $Z$ różnych stron kraju w obawie przed aresztowaniami na ten teren przybyło wielu nauczycieli szkół średnich, a nawet wyższych. W miejscach, gdzie znaleźli pomoc i schronienie, zazwyczaj organizowano tajne nauczanie. Oprócz Opatowa są wymieniane między innymi: Iwaniska, Planta, Raków. Jeden z badaczy odnotował:

\section{1) Komplety w Plancie prowadzil profesor Jan Parandowski i docent Uniwersytetu Wileńskiego biolog. Nazwiska tego ostatniego nie usta- lono. W I944 r. w tej małej wiosce koło Iwanisk odbył się egzamin doj- rzałości. Członkiem Komisji Egzaminacyjnej był mgr Edmund Ginter, obecny dyr. Techników [sic! - G. P.] Ekonomicznego w Ostrowcu ${ }^{26}$.}

W innym opracowaniu pojawiła się również informacja, że „Profesor Jan Parandowski” wykładał na tajnych kompletach $\mathrm{w}$ słynnym $\mathrm{z}$ ariańskich tradycji Rakowie $^{27}$. Ten ostatni, dość lakoniczny zapis budzi sporo wątpliwości. Wydaje się mało prawdopodobne, by dotyczyło to zajęć cyklicznych, choćby ze względu na znaczną odległość dzielącą Raków od dworu w Plancie (kilkanaście kilometrów). Nigdy też Parandowski nie wspominał o stałym zaangażowaniu w tajne nauczanie poza Plantą. Być może tak nazwano incydentalną prelekcję wygłoszoną dla zamkniętego grona słuchaczy? Natomiast dobrze pamiętał, że w 1944 roku dwukrotnie jeździł z odczytem na temat specyfiki warsztatu pisarskiego do pobliskich Gołoszyc, zapewne także do dworu, skąd - jak zanotował - wyniósł „śliczne wspomnienie" ${ }^{28}$. Może wiązało się to z dużo większym spokojem panującym w Gołoszycach. Właściciele byli bezdzietni i w zabudowaniach dworskich nie przebywało tak wielu uciekinierów jak w Plancie.

Autorka książki Dzień Jana, relacjonując pobyt w majątku Morawskich, potwierdzała funkcjonowanie w Plancie w latach I942-I944 placówki działającej pod oficjalnym szyldem szkoły handlowej, która stała się przykrywką dla organizowanych przez córkę właścicieli tajnych kompletów. $Z$ opowieści Parandowskiej dowiadujemy się, że jej mąż prowadził zajęcia z języka polskiego i łaciny, wspomniany profesor

25 T. Bernat, Bojownicy tajnego nauczania, „Mówią Wieki” 1967, s. 14.

26 Idem, Praca nauczycieli powiatu opatowskiego w latach okupacji hitlerowskiej (1939-1945), „Przegląd Historyczno-Oświatowy" 1971, nr 3, s. 434.

27 A. Massalski, Szkolnictwo na Kielecczyźnie w okresie okupacji 1939-1945, Warszawa-Kraków 1975, s. 128.

28 J. Parandowski, Luźne kartki, s. 93. 
Błachowski - wykłady z psychologii, przebywająca w Plancie z synem pani Białowąs z Warszawy uczyła matematyki, a ona- języka niemieckiego ${ }^{29}$.

Tradycja niesienia pomocy potrzebującym przez właścicieli dworu sięgała wiele pokoleń wstecz. Po upadku powstania listopadowego dwór w Plancie znalazł się w posiadaniu Ludwika Łempickiego. Senator Łempicki, patriota i uczestnik powstania listopadowego, był jednym z najbardziej świattych obywateli Sandomierszczyzny. Majątek należał wówczas do najlepiej zarządzanych dóbr w okolicy. Dzięki niemu Planta zaczęła promieniować swobodą myśli, wolnościowymi hasłami i pozytywistycznym programem działania. Pełniła też funkcję ośrodka kultury polskiej, porównywanego do Mickiewiczowskiego Soplicowa ${ }^{30}$. Kolejnymi właścicielami Planty stał się ród Morawskich. Ostatni właściciel majątku, Stanisław Morawski (I887-I946), wykształcony w Lipsku, Dreźnie i Monachium, biegle władał kilkoma językami (niemieckim, francuskim, rosyjskim), znał także grekę, a znajomość łaciny wystarczała mu na swobodną konwersację z odwiedzającym dwór biskupem. Wszystkim dzieciom zapewniano edukację na stosunkowo wysokim poziomie. Duży nacisk kładziono na rozwijanie umiejętności językowych, w tym celu zatrudniano bony, zazwyczaj rodowite Francuzki lub Niemki. W domu obowiązywała rygorystyczna zasada używania w rozmowach wyłącznie tego języka, którego dzieci się uczą. Jeśli dziecko nie potrafiło wypowiedzieć się w danym języku, musiało milczeć. W rezultacie dzieci bardzo szybko opanowywały umiejętność konwersacji w językach obcych. Nierzadko - jak wspominali potomkowie Morawskich - rozmowy przy stole prowadzono wyłącznie po francusku. Żona Stanisława, Olga z Duninów Morawska, absolwentka jarosławskiej pensji sióstr nazaretanek, aktywnie działała w sodalicji mariańskiej. Dla zakładu dla ociemniałych w Laskach przepisywała książki systemem Braille'a, narzucając sobie w tej pracy budzącą szacunek dyscyplinę. Bez względu na okoliczności starała się przepisać przynajmniej trzy strony tekstu dziennie. $Z$ wielkim oddaniem zajmowała się również dziećmi służby dworskiej, niosąc pomoc w chorobie, a dla wielu z nich była matką chrzestną. Dawni fornale długo pamiętali o jej zasługach i kilka lat po parcelacji majątku odnaleźli w Poznaniu byłą dziedziczkę, by wręczyć podpisany przez nich dokument, zaświadczający o jej prawości, oraz wspomóc dawną dobrodziejkę płodami ziemi opatowskiej ${ }^{3}$.

Pochodzący z drugiej połowy XVIII wieku dwór był skromny, z czterokolumnowym gankiem i łamanym polskim dachem, otoczony czworokątem starych drzew,

29 I. Parandowska, Dzień Jana, s. 73.

30 F. Faliszewski, Echo ziemi opatowskiej. Szkic monograficzno-wspomnieniowy z dziejów powiatu opatowskiego, Warszawa 1968, s. 44.

31 A. Hajduk, $W$ kolejce po równość... 
które ocieniały budynki, oraz rozległym starym ogrodem. Za dworem znajdował się płytki staw okolony wierzbami. Pod ogromnym kasztanem stał kamienny stół z ławkami z piaskowca. Ozdobę Planty stanowiły dwie wspaniałe aleje lipowe, prowadzące od dworu ku szosie wiodącej do Opatowa, także obsadzonej lipami. „Te aleje były starannie pielęgnowane. Gdy któreś drzewo uschło, na jego miejsce wsadzano nowe drzewko. Do dziś przechowało się kilkanaście lip, z tych wiele liczy na pewno 300 lat" - wspominał Franciszek Morawski ${ }^{32}$.

W czasie pierwszej wojny światowej majątek został poważnie zniszczony, ponieważ leżał na linii frontu i kilkakrotnie przechodził z rąk Austriaków do Rosjan. Zabudowania gospodarcze zostały spalone, a dwór niemal całkowicie zdewastowany. Po powrocie z internowania w I9I9 roku Morawscy odbudowali dwór ze zniszczeń wojennych, a w miarę powiększania się rodziny przebudowywali siedzibę, starając się uczynić ją wygodną i nowoczesną. Budowa Centralnego Ośrodka Przemysłowego (COP) w I934 roku otwierała możliwości elektryfikacji na terenach Kielecczyzny. Właściciele Planty skorzystali z tego, że duża część instalacji przebiegała przez ich dobra, i zamontowali we dworze oraz w czworakach oświetlenie elektryczne. Główny budynek był piętrowy z dużym holem, skąd wiodły schody na piętro. Znajdowało się w nim siedemnaście pokoi, cztery łazienki i pięć toalet. $\mathrm{Na}$ poddaszu usytuowano pokoje dla nauczycielek domowych oraz starszych dzieci. W reprezentacyjnych pomieszczeniach mieściła się galeria portretów poprzednich właścicieli Planty. Oszklone drzwi bibliotecznych szaf kryły wysmakowane kolekcje, wśród nich zbiór dawnych map Volumina Legum, oprawione w skórę herbarze, stare encyklopedie francuskie oraz, najbardziej cenione przez właścicieli, najstarsze wydania dzieł Mickiewicza i Słowackiego. W słynnej bibliotece, do której często zaglądał Parandowski, sięgając po ukryte tam tomy ${ }^{33}$, znajdował się bogaty zestaw cennych książek z przełomu XVIII i XIX wieku oraz kompletne roczniki polskich czasopism. Kolekcję uzupełniało bogate archiwum rodu Sołtyków i Łempickich. Niestety, po zabytkowym dworze, istniejącym jeszcze do 1947 roku, nie pozostał żaden ślad. Nieznacznie tylko uszkodzony w czasie działań wojennych, po wojnie został doszczętnie rozgrabiony. W następnych latach budynek rozebrano, a materiał wykorzystano do budowy drogi i okolicznych domów.

W sierpniu I944 roku zbliżająca się ofensywa wojsk radzieckich spowodowała, że w pobliżu Planty rozpoczęły się ciężkie walki. Zabudowania dworskie zostały poważnie uszkodzone, a mieszkańcy - zmuszeni do ukrywania się w ogrodowej piwnicy.

Po ucieczce Niemców do majątku weszli Rosjanie, którzy nakazali wszystkim opuścić posiadłość:

32 Planta. Franciszek Morawski opowiedziat..., s. 10.

33 J. Parandowski, Ostatni tom Tarnowskiego, w: idem, Wspomnienia i sylwety, Warszawa 1960, s. 150. 

\Wyszliśmy stamtąd na koniec, bo był to właściwie front, dookoła snuły się okopy, stały tanki, działa. Wyszliśmy w piękny dzień letni i Mamusia, trochę tylko zmęczona, doszła dzielnie do Ujazdu odda- lonego o parę kilometrów. Stamtąd ruszyliśmy dalej, do wsi Radwan, gdzie w stodole przebyliśmy dwa dni. I znów powędrowaliśmy dalej: do Suliszowa. Ciągnęliśmy jak obóz cygański. Kilka wozów, wyłado- wanych do ostatniej wytrzymałości i tylko małe dzieci i parę kobiet jechało, a reszta szła pieszo ${ }^{34}$.

Rozpoczął się kolejny rozdział wojennej tułaczki, odbywanej wozami drabiniastymi, niekiedy wojskowymi ciężarówkami, a najczęściej na piechotę. Rosjanie nakazywali marszrutę na wschód. Po drodze mijali miejscowości: Ujazd, Radwan, Suliszów, Sulisławice, Miechocin aż do Tarnobrzega. Nocowano zazwyczaj na wiązce słomy lub siana w stodołach, barakach lub pomieszczeniach gospodarczych. W Tarnobrzegu zakwaterowano wszystkich w oborze, w której aż nadto widoczne były ślady niedawnej obecności zwierząt. Stanisław Morawski uznał, że będąca tuż przed połogiem żona Parandowskiego nie powinna przebywać w takich warunkach. Przekonał Rosjan, że Parandowski to luminarz polskiej kultury i zasługuje na lepszą kwaterę, a także obiecał ją dla nich znaleźć. W tym celu zwrócił się z prośbą do administratora Dzikowa, który pod nieobecność właścicieli zgodził się na jakiś czas zakwaterować rodzinę w rezydencji Tarnowskich.

Decyzją Dekretu PKWN o reformie rolnej z listopada I944 roku rodzina Morawskich została pozbawiona prawa do rodzinnego majątku i podzieliła los tysięcy właścicieli ziemskich, zmuszonych odnaleźć się w nowej rzeczywistości. Wysiedleni z ojcowizny, pierwsze schronienie znaleźli w Tarnobrzegu, w części obory oddanej do dyspozycji uciekinierów, w której spędzili kilka dni. Właściciel Planty udał się do mieszkającego w pobliskim Grębowie sąsiada, Seweryna Dolańskiego, z prośbą o gościnę dla rodziny. Zostali przyjęci, niestety, na krótko. Po przejęciu majątku przez nowe władze i uwięzieniu właściciela, Morawscy znów stracili dach nad głową. $Z$ pomocą przyszedł miejscowy proboszcz, który przekazał im do zagospodarowania niewielką, murowaną salkę parafialną. Niedługo mogli się nią cieszyć, gdyż solidna konstrukcja budynku wzbudziła zainteresowanie miejscowej milicji, która zapragnęła urządzić w nim nową siedzibę. Morawskim nie pozostawiono wyboru, zostali zmuszeni do przeprowadzki do zajmowanego wcześniej przez funkcjonariuszy starego, drewnianego i mocno zapchlonego posterunku. Po raz kolejny pospieszył na ratunek proboszcz z Grębowa, ofiarowując rodzinie graniczący ze

34 Pamiętnik Piotrusia, w: Spuścizna Jana Parandowskiego, BN. Zakład Rękopisów, akc. 017692/03, rkps niepublikowany. Zapis pod datą 28 października $1944 \mathrm{r}$. 
szkołą niewielki budynek wikariatu. Przeżycia ostatnich lat i powojenna tułaczka mocno odbiły się na zdrowiu Stanisława Morawskiego. Poważnie zachorował (zdiagnozowano raka krtani), przewieziony do szpitala w Krakowie zmarł w styczniu 1946 roku. Tam też został pochowany w ziemnej mogile na Cmentarzu Rakowickim. W połowie 1947 roku wdowa z czwórką najmłodszych dzieci na krótko przeniosła się do córki Zofii, mieszkającej w Przysiece pod Poznaniem. Ostatecznie rodzina podjęła decyzję o wyjeździe do Poznania. W jednym ze zniszczonych domów, za cenę remontu zdewastowanego lokalu, Olga Morawska miała prawo zamieszkać wraz z czwórką najmłodszych dzieci. W maju 1948 roku rodzina wprowadziła się do nowego mieszkania w czteropiętrowej kamienicy przy ulicy Obornickiej 49. Po prawie czterech latach od wysiedlenia Olga z Duninów Morawska mogła cieszyć się własnym dachem nad głową. W nowych realiach polityczno-gospodarczych dawna właścicielka Planty, by uzyskać podstawowe zabezpieczenie emerytalne, na pięć lat została zatrudniona w charakterze dozorczyni domu. Dzięki solidarności rodzinnej nie musiała wykonywać ciężkiej pracy fizycznej, ponieważ wszelkie obowiązki pomagały wypełniać dzieci35. Jednak i tu los jej nie oszczędzał - w Poznaniu przeżyła jeszcze jedną tragedię. Jej najmłodsze dziecko, córka Olga, zmarła w wieku trzynastu lat na gruźlicze zapalenie opon mózgowo-rdzeniowych ${ }^{36}$. Matka przeżyła swoje dziecko niespełna o siedem lat. Zmarła w styczniu r959 roku i spoczęła na cmentarzu parafii św. Stanisława Kostki w Poznaniu.

Jedyne reminiscencje z pobytu w majątku Morawskich pojawiają się na stronach, pozostającego nadal w postaci rękopisu, Pamiętnika Piotrusia ${ }^{37}$. To rodzaj kroniki rodzinnej, utrzymanej w tonie opowieści, której adresatem jest najmłodszy syn pisarza, Piotr, urodzony w ostatnim roku wojny. Pierwsze zapiski pochodzą z I944 roku i mają charakter doraźnych notatek różnej objętości, zazwyczaj datowanych. W skierowanej do nowo narodzonego syna relacji, dotyczącej przeżyć z ostatnich lat, pojawiły się akcenty niechęci do wspólmieszkańców podopatowskiego dworu (zapis pod datą 28 października I944 roku):

\ Mieszkaliśmy w Plancie, gdzie wszystko, co pochodziło od Boga było dobre, a co od ludzi niemiłe. Był tam krajobraz łagodny, i cisza wiejska wśród pól i lasów i ogród, w którym Mamusia uprawiała sobie parę własnych grządek z rzodkiewką, marchewką, cebulą, ogórkami,

35 Taki obraz wyłania się z rozmowy z obiema córkami, Anną Hajduk i Teresą Leitgeber, oraz synem Edwardem Morawskim.

36 Wedle przekazów rodzinnych do zarażenia prątkami gruźlicy doszło w szkole. Olga była jedną z trójki uczniów zmarłych w wyniku zarażenia. Każda z ofiar siedziała w tej samej szkolnej ławce. Podejrzewano, że skażone zostało drewno ławki, w rezultacie podjęto decyzję o jej spaleniu. 
pomidorami i odrobiną kwiatów. Ludzie dookoła byli niegrzeczni i dokuczliwi ${ }^{3}$.

Obraz Planty, jaki wyłania się z kart Pamiętnika Piotrusia, wydaje się nacechowany pejoratywnie. Nie sposób doszukać się w nim choćby cienia wdzięczności dla właścicieli majątku, którzy w czasie okupacji zaprosili do siebie pisarza z żoną Żydówką oraz dwójką dorastających dzieci i udzielili im gościny na okres bez mała dwóch lat. W najlepszym przypadku Planta jawi się jako „cicha, poczciwa, zapadła wieś”. W innym miejscu odgrywa rolę krzywego zwierciadła przywołującego przykre wspomnienia, jak przy opisie domu w Ciechankach, do którego skierowano wyczerpanych przeżyciami wojennymi literatów: „Znów, jak w Plancie, jesteśmy w walącym się domu. Dach przecieka, rynny złamane leżą na ziemi”39.

Wydaje się, że czynnikami determinującymi negatywne postrzeganie Planty przez Parandowskiego były stres i niepewność jutra, towarzyszące rodzinie w ostatnich latach wojny. Stan zagrożenia podsycały rewizje przeprowadzane przez Niemców oraz lęk przed ujawnieniem pochodzenia żony i wynikającymi stąd konsekwencjami. Warto również pamiętać o zdecydowanie niechętnym stosunku Parandowskiego do najszerzej rozumianego pojęcia prowincji. Nie lubił małych miejscowości, czuł się w nich osaczony, odcięty od świata, organicznie nie znosił małomiasteczkowej mentalności. Wieś tolerował wyłącznie jako miejsce krótkotrwałego wypoczynku. Nie znał jej, nie rozumiał i nie doceniał, ale też nie budziła jego zainteresowania. Miał do niej stosunek niemal klaustrofobiczny, nadto ciągły stres związany z zagrożeniem ze strony Niemców i brak podniet intelektualnych tworzyły zbitkę trudną do zaakceptowania. Przybywając do Planty, z pewnością wiedział, że ratuje życie swoje i bliskich, mimo to czuł się wyrwany z własnego środowiska, całkowicie odizolowany, niemalże jak więzień bez wyroku. Znalazł się wśród ludzi żyjących w odmiennym rytmie, w dodatku był jednym $z$ uciekinierów, jakich wielu przekraczało progi tego domu. Zdany na łaskę swoich gospodarzy i dyskrecję innych domowników musiał odbierać to jako dotkliwe ograniczenie. Mimo czasowego dystansu przeżycia i związane z nimi emocje przesłoniły perspektywę oraz utrwaliły zniekształcony obraz pobytu na wsi. Z lektury dalszych zeszytów Pamiętnika Piotrusia można wnosić, że po wojnie Parandowscy sporadycznie utrzymywali kontakty z byłymi już właścicielami majątku. Pod datą 3 marca I950 roku widnieje zapis:

\section{》Wczoraj około I2 w nocy wróciliśmy z Mamusią z 3-dniowej wizyty w Poznaniu. Miałem tam odczyt w pięknej Sali ratuszowej, na której}


znać dymy pożaru w czasie wojny. Było moc ludzi, ścisk, parę młodzieńców po prostu wisiało u sufitu. Bardzo mnie serdecznie witano. Czytałem rozdział z „Alchemii” - „Sława i nieśmiertelność”. Mamusia była $\mathrm{b}[\operatorname{ardzo}]$ zadowolona. Po odczycie byliśmy na kolacji z tuzinem literatów. Dużo widywaliśmy Morawskich z Planty, którzy tam prawie wszyscy się zgromadzili.

Jan Parandowski spotkał się $\mathrm{z}$ dawnymi dziedzicami Planty przy okazji zaproszenia na utrwalone tradycją czwartki literackie w Poznaniu. Występował w glorii uznanego, stołecznego pisarza, który przybywa, żeby nawiązać kontakt z lokalnym środowiskiem literackim oraz ze swoimi czytelnikami. Jak dalece zmieniły się wówczas role, świadczy fakt, że on z żoną zamieszkał w luksusowym hotelu Continental, a dawna właścicielka Planty zajmowała z czwórką dzieci niewielkie dwupokojowe mieszkanie. W ostatnim, niemal przypadkowym napomknieniu o rodzinie Morawskich, jakie zostało odnotowane w Pamiętniku Piotrusia pod datą I6 marca I95I roku, pobrzmiewa protekcjonalny ton: „Mamusia posłała Oldze Morawskiej puszkę szynki (cała szynka bez kości)".

Plantowski epizod biografii Parandowskiego powracał jeszcze kilkakrotnie w następnych latach. Przede wszystkim za sprawą wydanej niespełna dwie dekady później powieści Powrót do życia. Jej treść nawiązuje do czasu spędzonego w podopatowskim dworze. Przedstawione z werystyczną dokładnością realia i opis miejsca nie pozostawiały wątpliwości, że akcja została osadzona w tym właśnie majątku. Niezbyt pochlebny, literacki wizerunek właścicieli posiadłości budził żal potomków rodziny Morawskich. Brat ostatniej właścicielki Planty we wspomnieniach, pisanych dwadzieścia lat po wojnie, notował z goryczą:

\W książce Powrót do życia opisał Parandowski swój pobyt w Plancie w czasie okupacji niemieckiej. Niestety, nie wyraził w tych wspomnieniach wdzięczności ani uznania czy podziwu za odwagę i miłość prawdziwie chrześcijańską, którą im okazała moja Siostra i Szwagier z narażeniem siebie i całego domu na tragiczne konsekwencje, które mogły Ich spotkać, za udzielenie tej gościny. Jak dalece stworzono im w tych strasznych czasach bezpieczny azyl świadczy fakt, że żona Parandowskiego, tak zatraciła zmysł rzeczywistości i tak czuła się bezpieczna, że chciała pojechać do Warszawy, zobaczyć swoje mieszkanie ${ }^{40}$.

40 J.S. Dunin, Millennium Duninorum. Comitum Skrzinnesium, t. 3a, s. 83. Zakład Narodowy im. Ossolińskich we Wrocławiu. Dział Rękopisów, sygn. 15399/II [maszynopis]. W tym miejscu pragnę gorąco podziękować p. Wojciechowi W. Wiśniewskiemu za udostępnienie mi materiału jeszcze przed publikacją. 
Z tego zapisu wynika, że Irena Parandowska jednak nie ,jeździła do Warszawy”, jak sugerowała w Dniu Jana (s. 74), a jedynie miała taki zamiar, który zapewne szybko jej wyperswadowano. W czasie wojny wszelkie wyprawy pociągiem, szczególnie do stolicy, były obarczone zbyt dużym ryzykiem. Podwójnym, jeśli miałaby je podejmować osoba o rysach mogących choćby uchodzić za semickie, a tak było w przypadku żony Parandowskiego. W razie aresztowania naraziłaby na śmiertelne niebezpieczeństwo nie tylko siebie, ale bez wątpienia także pozostałych mieszkańców Planty.

W podobnym tonie rozżalenia jest utrzymana wypowiedź męża jednej z córek właściciela Planty: „W chwili przybycia rodziny Parandowskich do dworu w Plancie mury siedziby Morawskich pękały w szwach, mimo to jednak zostali przyjęci z otwartymi ramionami, co niestety bardzo szybko poszło w zapomnienie"4I. Kolejny raz dwór w Plancie został przywołany w książce Ireny Parandowskiej Dzień Jana (s. 73-77) oraz w zainspirowanych nią artykułach prasowych ${ }^{42}$.

W pamięci żyjących potomków Stanisława Morawskiego, z którymi udało się porozmawiać, Parandowscy jawili się jako ludzie kompletnie zagubieni w otaczającej ich rzeczywistości. Nie rozumieli specyfiki wiejskiego życia, nie chcieli także przyjąć do wiadomości wynikających z niej ograniczeń i uciążliwości. Stąd częste utyskiwania Parandowskiego na odór czy wszechobecne muchy. Niemal na każdym kroku manifestowali swoją przynależność do innego świata. Taka postawa przez rodzinę Morawskich była odbierana jako chęć „wywyższania się” i tworzyła dystans trudny do przezwyciężenia dla obu stron. Być może również w tym należy doszukiwać się niechęci Parandowskiego do wspomnień z tego okresu?

\section{BibliogRAFIA}

Bernat T., Bojownicy tajnego nauczania, „Mówią Wieki” 1967, nr 8, s. 14.

Praca nauczycieli powiatu opatowskiego w latach okupacji hitlerowskiej (1939-1945), „Przegląd Historyczno-Oświatowy" 1971, $\mathrm{nr} 3$.

Biografie stawnych ludzi, t. 2, Bochnia 2006.

Biogramy uczonych polskich, cz. 1: Nauki spoteczne, z. 3: P-Z, oprac. A. Śródka, P. Szczawiński, Wrocław 1985.

Borzęcki J.A., Myjak J., Sandomierskie Soplicowo, „Tygodnik Nadwiślański” 1984, nr 22.

Dunin J.S., Millennium Duninorum. Comitum Skrzinnesium, t. 3a, s. 83. Zakład Narodowy im. Ossolińskich we Wrocławiu. Dział Rękopisów, sygn. 15399/II [maszynopis].

Faliszewski F., Echo ziemi opatowskiej. Szkic monograficzno-wspomnieniowy z dziejów powiatu opatorwskiego, Warszawa 1968.

Gabis N., Żotnierze niezwyciężonej szkoty. Wspomnienie o nauczycielach tajnego nauczania w latach 1939-1945, Zielona Góra 1993.

41 S. Leitgeber, Jan Parandowski (1895-1978), „Gazeta Wielkopolska” 2000, nr 287, s. 3.

42 J.A. Borzęcki, J. Myjak, Sandomierskie Soplicowo, „Tygodnik Nadwiślański” 1984, nr 22, s. 7. 
Goetel F., Czasy wojny, Londyn 1955.

Grydzewski M., Silva rerum, wybór J.B. Wójcik, M.A. Supruniuk, Warszawa 2014.

Hajduk A., W kolejce po równość. Polska 1945-1956 w opowieściach kobiet. Rozmowę przeprowadziła A. Kaczorowska. Sygnatura nagrania: AHM_2857. Miejsce nagrania: Wolsztyn; data nagrania: 15 listopada 2012. Format: mp3, Warszawa: Ośrodek Karta. Archiwum Historii Mówionej.

Leitgeber S., Morawscy herbu Natęcz I. 600 lat dziejów rodziny, Poznań 1997.

Jan Parandowski (1895-1978), „Gazeta Wielkopolska” 2000, nr 287.

Literatura polska XX wieku. Przewodnik encyklopedyczny, t. 2: P-Z, Warszawa 2000.

Maciąg W., Literatura Polski Ludowej 1944-1964, Warszawa 1973.

Massalski A., Szkolnictwo na Kielecczyźnie w okresie okupacji 1939-1945, Warszawa-Kraków 1975.

Pamiętnik Piotrusia, w: Spuścizna Jana Parandowskiego, BN. Zakład Rękopisów, akc. 017692/03, rkps niepublikowany.

Planta. Franciszek Morawski opowiedziat historię rodzinnego majątku w Plancie, [not.] A. Gromek-Gadkowska, „Ziemia Opatowska” 2000, nr 17.

Parandowska I., Dzieñ Jana, Warszawa 1983.

Parandowski J., Luźne kartki, Wrocław 1967.

Ostatni tom Tarnowskiego, w: idem, Wspomnienia i sylwety, Warszawa 1960.

Wrześniowa noc, Warszawa 1962.

Stownik wspótczesnych pisarzy polskich, t. 2: J-P, oprac. zespół pod red. E. Korzeniewskiej, Warszawa 1964. Sułowski A., U podnóża Gór Świętokrzyskich. Z dziejów obwodu Opatów ZWZ-AK 1939-1945, Warszawa 1987.

Termer J., Leksykon prozaików dla szkót i mitośników literatury, Warszawa 2001.

Tuszyński B., Polscy olimpijczycy XX wieku (1924-2002): N-Ż, Wrocław 2004.

Wańkowicz M., Anoda i katoda, t. 1, wstęp A. Szwedowicz, Warszawa 2011.

Zawadzki J.M., Senatorowie. Losy wojenne i powojenne, Warszawa 2012.

SŁowa Klucze: Jan Parandowski, Morawscy, Planta, wojna, terror, tajne nauczanie

\section{AN EPISOde in THE WARTIME Biography OF Jan PaRandowski. The Planta estate outside of Opatów}

The article concentrates on a small excerpt from the biography of Jan Parandowski, covering a two-year stay of the writer on the estate of the Morawscy family in Kielce Voivodeship. The article presents, using this singular example, the life of a Polish manor house during the German occupation. The mansion was crowded with refugees and displaced people, forced to deal with the wartime reality. The image of this community is dominated by the owners of the estate, a family whose tradition and ethos obligates them to take on difficult and dangerous challenges. In the face of the still-circulating incomplete, or false, information relating to the 
II2

place of stay of the writer following his departure from Warsaw, the main aim of this text is to systematise the knowledge and to remove doubt surrounding this topic.

KeY words: Jan Parandowski, Morawscy, Planta, World War II, terror, underground education 